\title{
ON THE INHERITANCE OF FEMALE STERILITY IN CATTLE.
}

\author{
By Nils Korkman. \\ Institute of Animal Breeding, Royal Agricultural College of Sweden. \\ Received 10. 12. 1947.
}

\section{Introduction.}

Previous investigations show quite clearly that there are hereditary factors in cattle influencing the reproduction capacity of the cows. FINCHER and WILLIAMS (4) observed that by inbreeding to a certain sire part of the female offspring exhibited an arrested development of the Muellerian ducts. ERIKsson (3) established, in the Swedish highland breed, hereditary hypoplasia of the ovaries and the testicles, tracing the reason to a recessive autosomal hereditary factor with incomplete penetrance. The author made a similar observation in a Ayrshire herd in South-Finland (Korkman (7)). In all these cases it is thus a question of inheritability of certain deficiencies in the reproductive organs. But also in cases in which such deficiencies could not be noticed, hereditary differences in reproduction capacity were observed. Thus e. g. WAGNER (15) amd Löwe (9) in this respect staet that there are differences between groups of daughters of different sires just as other authors have established differences between the groups of offspring of different dams (Spielman, Arless and Jones (13)), Jones, Dougherty and Haag (6) and Trimberger and Davis (14)), without, however, further elucidating the inheritance. BERGE (1) calculated the intra-cow correlation with respect to the number of services pro pregnancy, and found the coefficient $0,213 \pm 0,051$. The difference between the individuals was thus quite significant. It does not, however, appear from the investigation if the circumstance that the environment might have been more of a similar kind during the life time of one cow than of the whole material, was duly considered. GREGORY, REgAn and MeAD (5) show than in material investigated by them, sterility is more frequent in cows with a higher inbreeding coefficient than in cows with a lower one, and the same authors (MEAD, GrEGory and REGAN (10)) further establish that by inbreeding to certain sires, the daughters have a greater tendency to sterility than cases in which there was outbreeding. The authors mentioned account for the results by a recessive hereditary factor of sterility being in these cases inherited from the sire. 
It has thus been proved that hereditary sterility of various kinds exist. The question of how great a part of the variation as to how the cows become pregnant should be referred to genetic variations between the individuals has, however, not been examined. The purpose of this investigation is to elucidate this problem. The investigation does not deal with definite disturbances in the functions of the sexual organs.

\section{Material and method.}

The material for this investigation is the same as that on which a previous research by the author was based (KORKMAN (8)); in his paper the author gave an accurate account of the collection of the material. This material comprises statements on the reproduction of the cows in 38 Ayrshire herds in southern Finland during the years 1931-1937. All these herds were free from tuberculosis and infectious abortion during this period. The feeding and the yield varied between the different herds, but were the same within them from year to year. The greatest variation between the average yield of the different years was a divergence of 10 per cent from the average yield for all years. The material comprises 4.009 cows with a total of 13.119 calvings. The mean calving interval was 382,4 days, and for inducing a pregnancy was on an average 1,57 services required. Discarding because of sterility was, on an average, 7,6 pro 100 service periods, and the average age of the cows was 6,9 years. The fertility in the investigated herds must thus be considered a fairly good average.

The statistical treatment of the material is made in accordance with common principles presented i.a. by SNedecor (12) and Bonnier and Tedin (2). The various parts of variance are calculated according to the method developed by Winsor and Clark (16).

\section{Temporary sterility.}

The first part of the investigation deals with the problem whether there are individual and hereditary differences between the cows regarding how easily they conceive after calving. In order as far as possible to eliminate the influence of a varying veterinary treatment upon the reproduction of the cows, the author, as also in a previous research (KORKMAN (8)), investigated whether the cow was pregnant or not after the first service. Veterinary interference before the first service was, as a matter of fact, very rare at the time of this investigation. The two variables, which frequencies were compared, were the following: 1) pregnant after 1 service, this variable being indicated by 1 in the analysis, and 2) not pregnant after 1 service, this variable being indicated by 0 .

Within the herds the feeding and the yield of the cows were, as already mentioned, homogenous during the total period of this investigation, whereas considerable differences existed between the different stocks. Thus e. g. the yield of milk of the various stocks calculated in $\mathrm{kg}$ of 4 per cent corrected milk pro day, varied between minimum 7,34 and maximum 13,74 . In order to eliminate the influence of diffe- 
Table I. Analysis of the variance in the conception of cows after the first service.

\begin{tabular}{|c|c|c|c|c|}
\hline \multirow[b]{2}{*}{ Cause of variation } & \multirow{2}{*}{$\begin{array}{l}\text { Degree } \\
\text { of } \\
\text { freedom }\end{array}$} & \multirow{2}{*}{$\begin{array}{l}\text { Mean } \\
\text { square }\end{array}$} & \multicolumn{2}{|c|}{ Calculated variance } \\
\hline & & & $\sigma^{2}$ & $\begin{array}{c}\% \text { of the } \\
\text { total variance }\end{array}$ \\
\hline Between herds $\ldots \ldots \ldots \ldots \ldots \ldots \ldots$ & 37 & $\left.2,12105^{1}\right)$ & 0,00468 & 1,92 \\
\hline Between age groups .............. & 203 & $\left.0,50378^{1}\right)$ & 0,00384 & 1,57 \\
\hline Between the sires of the cows .... & 633 & $\left.0,29490^{2}\right)$ & 0,00288 & 1,18 \\
\hline Between cows $\ldots \ldots \ldots \ldots \ldots$ & 3135 & $\left.0,25172^{1}\right)$ & 0,00848 & 3,48 \\
\hline Within cows $\ldots \ldots \ldots \ldots \ldots$ & 9110 & 0,22398 & 0,22398 & 91,85 \\
\hline Total $\ldots \ldots \ldots \ldots \ldots \ldots \ldots \ldots$ & 13118 & 0,24370 & 0,24386 & 100 \\
\hline
\end{tabular}

rences in the feeding on the fertility of the cows, the variance caused by differences between the herds was first deducted whereafter the variance was calculated within herds. Besides the fact that variations in feeding influences the fertility of cows, the influence of age on the facility of conception has, based on the same material, been earlier investigated by the author (KoRkman (8)). For this reason the cows within the separate herds were divided into age groups, cows born in the years 1916 - 18 being referred to one group, those born 1919-21 to another etc., always maintaining a range of 3 years. Within these age groups the daughter groups of the various sires were compared, and finally the different cows within the daughter groups were compared. The result of the analysis appears from table 1 .

It appears that there is a quite significant difference within herd and within age groups between the groups of offspring of the various sires, as also a significant difference between paternal half-sisters.

The intra-cow correlation within herds and age groups is $\frac{B+C}{A+B+C}$ in wich $\mathrm{A}=\sigma^{2}$ within cows, $\mathrm{B}=\sigma^{2}$ between cows within sires of the cows, and $\mathrm{C}=\sigma^{2}$ between the sires of the cows. Calculated in this way the intra-cow correlation is 0,0483 .

That part of the total variance which applies to differences between the sires of the cows, constitutes also a measure of the correlation between paternal halfsisters. This correlation is thus $0,0118(\mathrm{P}<0,001$.) The total genetically conditioned variance may therefore be calculated thus: The correlation is multiplied by 4 , resulting in a genetically conditioned variance of 0,0472 or 4,72 per cent. This value corresponds well with the obtained intra-cow correlation which indicates that there is principally an additive inheritance only.

The hereditary part of the total variance is thus unimportant, but if this part of the variation between cows is calculated, the importance of heredity in relation to environment is evident. Only 24 per cent of this variation was, in fact, caused by differences between herds and 19 per cent of variations in the age of the cows, 14 per cent being caused by differences between the sires of the cows and 43 per cent by individual differences between paternal half-sisters.

1) $\left.\mathrm{P}<0,001 ;{ }^{2}\right) \mathrm{P}<0,01$. 


\section{Discarding because of sterility.}

This part of the investigation deals with the problem whether the discarding of some cows of a certain age due to sterility, and the inclusion of others, are due to enviromental causes only, or there are individual and hereditary differences between the cows in this respect. The analysis was made in the same way as in the former case, and was based on the same grouping. The following cases were considered as variables: 1) the cow discarded due to sterility, indicated by 1 and 2) the cow not discarded due to sterility, indicated by 0 . The result of this analysis appears from table 2 .

Table 2. Analysis of the variance in the fertility of cows as manifested by some cows afrer a certain calving being discarded due to sterility and others not.

\begin{tabular}{|c|c|c|c|c|}
\hline \multirow{2}{*}{ Cause of variance } & \multirow{2}{*}{$\begin{array}{c}\text { Degre } \\
\text { of } \\
\text { freedom }\end{array}$} & \multirow{2}{*}{$\begin{array}{l}\text { Mean } \\
\text { square }\end{array}$} & \multicolumn{2}{|c|}{ Calculated variance } \\
\hline & & & $\sigma^{2}$ & $\begin{array}{l}\% \text { of the } \\
\text { total variance }\end{array}$ \\
\hline Between herds & 37 & $\left.0,14731^{4}\right)$ & - & - \\
\hline Between age groups ............... & 203 & $\left.0,20528^{1}\right)$ & 0,00360 & 5,11 \\
\hline Between the sires of the cows $\ldots$. & 633 & $\left.0,10948^{1}\right)$ & 0.00179 & 2,54 \\
\hline Between cows $\ldots \ldots \ldots \ldots \ldots$ & 3135 & $\left.0,08268^{1}\right)$ & 0,00777 & 11,04 \\
\hline Within cows $\ldots \ldots \ldots \ldots \ldots$ & 9110 & 0,05725 & 0,05725 & 81,31 \\
\hline Total ............. & 13118 & 0,06979 & 0,07041 & 100 \\
\hline
\end{tabular}

There is also in this case quite a significant difference within herds and age groups between the groups of offspring of the various sires, and between paternal half-sisters.

The part of the total variance assigned to differences between the sires of the cows is also in this case a measure of the correlation between paternal half-sisters, when this number is multiplied by 4 , the value 0,1016 or 10,16 per cent is obtained, this being a measure of the hereditary part of the total variance.

Although this investigation does not deal with the variance resulting from differences between herds and between age groups, it should be mentioned, however, that the analysis in tables 1 and 2 do not furnish an adequate picture of this influence. There is a certain interaction between both these factors, and the result will therefore be different should the herds be compared with one another within the corresponding age groups. The variation between herds with regard to discarding of the cows because of sterility, is therefore in this case significant $(P<0,05)$. Also the variance caused by variations between herds, although calculated in this way, is only 0,40 per cent of the total variance, whereas the variance caused by variations between the age groups is 4,48 per cent.

1) $\mathrm{P}<0 ; 001 ; 4) \mathrm{P}>0,05$. 
The principal part of variance between cows is, in this case, caused by individual differences between the animals. Thus 14 per cent of this variation is occasioned by differences between the sires of the cows, and 59 per cent of individual differences between paternal half-sisters.

\section{Discussion and conclusions.}

The investigation proves that temporary sterility partly depends on differences between the herds. It seems evident that the environment is of considerable importance in determining the number of services necessary for the fecundation of a cow. No doubt differences in the feeding are of certain importance (KoRKMAN (8)), but differences in the reproductive efficiency of the sires may possibly also be of importance, although this question, because of the nature of the material, could not be studied. The influence of age is also quite evident although not of dominating importance. However, discarding due to sterility seems to be less dependant of the environment as this appears in differences between herds, whereas the age of the cows is of great importance in this respect. This influence of age has earlier been elucidated by the author (Korkman $(8)$ ), and the present analysis thus confirms the results previously obtained.

The hereditary differences between the animals are evident both with regard to the cows conseiving already after one or only after several services, and as to whether they conceive at all or not. The inheritance seems, however, to be of greater importance with regard to discarding due to sterility than with regard to a temporary sterility manifested in the fact that the cows do not conceive after the first, but after some of the following services. The importance of heredity in the latter case shows that variations in the length of the cow's life is largely due to gentic differences between the cows. The observation that the length of life depends on certain hereditary factors, has also earlier been made by several authors (i. a. 11).

The most important conclusions which can be drawn from the results of this investigation are:

1. There are individual and hereditary differences between the cows in regard to how easily they conceive after calving, and also as to whether they conseive again at all.

2. Of the total variance as to whether the cows conceive after the first service or not, about 5 per cent can be ascribed to genetic differences between the cows.

3. Of the total variance as to whether the cows conceive aiter calving or not, about 10 per cent can be ascribed to genetic differences betueen the cows. 


\section{LITERATURE CITED.}

(1) Berge, S., Fruchtbarkeitsverhältnisse beim roten hornlosen Ostlandrind. - Zeitschr. f. Tierzüchtung u. Züchtungsbiologie 52: 127-167. 1942.

(2) Bonnier, G. \& Tedin, O., Biologisk variationsanalys. 325 pp. Stockholm 1940.

(3) Eriksson, K., Hereditary forms of sterility in cattle. Biological and genetical investigations I. 155 pp. Lund 1943.

(4) Fincher, M. G. \& Williams, W. L., Arrested development of the Muellerian ducts associated with inbreeding. - Cornell Vet. 26 (1): 1-19. 1926.

(5) Gregory, P. W., Regan, W. M. \& Mead, S. W., Evidence of genes for female sterility in dairy cows. - Genetics 30: 506-517. 1945.

(6) Jones, I. R., Dougherty, R. W. \& HAaG, J. R, Reproductive performance in dairy cattle.Oreg. Agr. Exp. Sta. Bull. 395. 27 pp. 1941

(7) Korkman, N., Bidrag till frågan om ärtfliga anlag för sterilitet hos våra mjölkkor. — Nordisk Jordbruksforskning $4-7$ : 226-229. 1938 .

(8) Korkman, N., Om orsakerna till variationen i kornas fruktsamhet i några ayrshirebesättningar i södra Finland. - Acta Agralia Fennica 64 (1): 1-107. 1946.

(9) Löwe, H., Abhängingkeit und Vererbung der Fruchtbarkeit bei den grossen landwirschaftlichen Haustieren unter besonderer Berücksichtigung des Rindes. - Kühn-Arch. 51 (2): 71-267. 1938.

(10) Mead, S. W., Gregory. P. W. \& Regan, W. M., Deleterious recessive gene in dairy bulls selected at random. - Journ. Dairy Sci. 29 (8): 557-558. 1946.

(11) Pearl, R., Constitutional factors in longevity. - Zeitschr. Morph. Anthr. 34: 314 -320. 1934.

(12) Snedecor, G. W., Statistical methods. Ames. Iowa. 388 pp. 1938.

(13) Spielman, A. \& Jones, I. R., The reproductive efficiency of dairy cattle. - Journ. Dairy Sci. 22 (5): $329-334.1939$.

(14) Trimberger, G. W. \& Davis, H. P., Predictability of breeding efficiency in dairy cattle from their previous conception rate and f1om their heredity. - Journ. Dairy Sci. 28 (9): 659 669. 1945

(15) Wagner, H., Sterilität und Vereıbung (Kann das männliche Tier Überträger einer Minderwertigkeitsanlage im Geschlechtsapparat sein?) - Deutsche Tierärtzliche Wochenschr. 40 (35): 547-550. 1932.

(16) Winsor, C. P. \& CLARK, G. L., A statistical study of variation in the catch of plankton nets. J. Marine Res. 3 (1): 1-34. 1940. 


\title{
SELOSTUS.
}

HEDELMÄTTÖMYYDEN PERIYTYMISESTÄ NAUTAKARJASSA.

\author{
Nils Korkman
}

Ruotsin Kuninkaallisen Maatalouskorkeakoulun Rotu- ja Jalostusopillinen Laitos.

38:sta eteläsuomalaisesta ayrshirekarjasta vuosina $1932-37$ kerättyjen tietojen perusteella pyrittiin selvittämään missä määrässä vaihtelut lehmien tiinehtyväisyydessä johtuvat perinnöllisistä tekijöistä. Tässä mielessä tutkittiin muunteluanalyysimenetelmää käyttäen eroavaisuudet eri sonnien jälkeläisryhmien ja eroavaisuudet isänpuolisten sisarusten välillä sekä tilapäisen että pysyväisen hedelmättömyyden ilmenemisessä. Tilapäistä hedelmättömyyttä tutkittaessa annettiin niille tapauksille, joissa lehmät tiinehtyivät ensimmäisellä astutuksella, arvo 1, ja niille tapauksille, joissa lehmät eivät tiinehtyneet ensimmäisellä astutuksella, arvo 0. Pysyväistä hedelmättömyyttä tutkittaessa annettiin niille tapauksille, joissa lehmät tiinehtyivät, arvo 1, ja niille tapauksille, joissa lehmät poistettiin mahoina, arvo 0 .

Tutkimus osoittaa, että samoissa karjoissa olevista samanikäisistä lehmistä kokoonpantujen eri sonnien jälkeläisryhmien välillä on eroja sekä tilapäisen että pysyväisen hedelmättömyyden ilmenemiseen nähden. Todennäköisyys, että todetut erot johtuisivat ainoastaan satunnaisista syistä, on edellisessä tapauksessa pienempi kuin 1: 100 ja jälkimäisessä tapauksessa pienempi kuin 1: 1000. Myös samoissa karjoissa olevien samanikäisten isänpuolisten sisarusten välillä on mainituissa suhteissa eroja, ja todennäköisyys, että nämä erot johtuisivat ainoastaan satunnaisista syistä, on pienempi kuin $1: 1000$. Suurin osa lehmien tiinehtyväisyyden vaihteluista, johtuu kuitenkin satunnaisista tai tutkimuksessa selvittämättömiksi jääneistä syistä. Perinnöllisistä tekijöistä on laskettu johtuvan ainoastaan noin $5 \%$ vaihtelusta, joka aiheutuu siitä, että lehmät joko tulevat tai eivät tule tiineiksi ensimmäisellä astutuksella. Vastaavasti noin $10 \%$ vaihtelusta, joka johtuu siitä, että lehmät joko tulevat tiineiksi tai poistetaan mahouden takia, on perinnöllisten tekijöiden aiheuttamaa. 